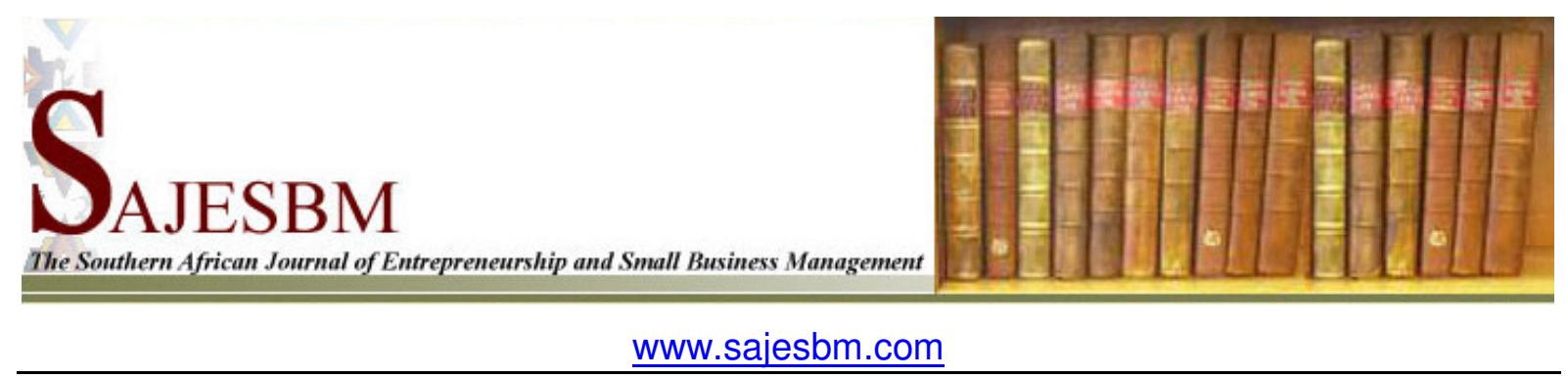

\title{
The prospects of making small retail outlets in the townships aggressively competitive
}

Malefane Johannes Lebusa

Centre for Innovation and Entrepreneurship

Vaal University of Technology

johannesl@vut.ac.za

\begin{abstract}
Historically, township Small Retail Outlets were mostly established for survival and operated under a generally closed market system where the competition was not very strong. However, with the advent of democracy many people lost their formal income through retrenchments and out of desperation, many of these people opened Small Retail Outlets thus most of the existing and new entrants into the township market were unskilled or semiskilled labourers with little or no formal skills in business or entrepreneurship. Such efforts were rarely guided by any specific and informed strategy of identifying and exploiting a gap in the market. With the consolidation of the free market system under democracy, big brand businesses such as Shoprite Checkers and Small Retail Outlets of foreign nationals with different strategies entered and competed in this township market. With fewer formal skills in business and entrepreneurship, the owners of the Small Retail Outlets struggled to compete and thrive under these relatively new economic conditions. Given this situation, I conducted semi-structured interviews with fifteen of these traditional Small Retail Outlets to find out and better understand the challenges they face and the skills that might be needed to aggressively compete in this space. Based on these findings and understandings, I further examined these issues and suggest infusions of specific entrepreneurship skills that could develop their aggressive competitiveness.
\end{abstract}

Keywords: entrepreneurship, competitiveness, small retail outlets, shopping complexes, innovation 


\section{PROBLEM STATEMENT}

Governments worldwide have acknowledged the impact of Small, Micro and Medium Enterprises (SMME) on job creation, improvement of the standards of living and hence an overall impact on the economy. In South Africa up to $50 \%$ of new small businesses including small retail outlets fail within the first 3-5 years of their creation (Ladzani \& Van Vuuren, 2002:154). The Global Entrepreneurship Monitor (GEM 2011) further revealed that South Africa has reported the lowest entrepreneurial activity rate of all developing countries included in the survey.

The country at large is faced with the challenge of developing more entrepreneurs and, more importantly, to make owners of small retail outlets to run these entities more efficiently (Krueger, 2007:132), to expand the participation of the black population in the entrepreneurial formal sector, and to increase the proportion of economic activity in the small business sector (Grundling \& Steynberg, 2008:12). It is not surprising, therefore, that it is now widely held that an alternative for South Africa is to make small retail outlets to be aggressively competitive in order to address unemployment and revitalise the economy (Co \& Mitchell,2006:348).

Small retail outlets (shops, tuck-shops, spaza-shops, informal and formal traders) defined as stores that purchase goods from manufacturers or wholesalers and sell (generally in small quantities) directly to consumers, including formal traders have historically been established out of desperation rather than through identification and exploitation of a gap in the market (Chetty \& Campell-Hunt, 2003:8). As the result of their genesis, most of the owners of the Small Retail Outlets lacked the requisite business and entrepreneurship skills on which to depend as the economic conditions of the country changed. With the new democratic dispensation came the consolidation of the free market system which posed new challenges to existing Small Retail Outlets (traditional) especially in the townships which were used to claiming such a market as almost a birth right.

When big brand businesses such as Shoprite Checkers and Small Retail Outlets of foreign nationals mushroomed across the townships to claim the slice of the market, traditional Small Retail Outlets struggled to compete and survive. Given the general lack of business and entrepreneurship skills from these owners, it is not unreasonable to suggest that their lack of a competitive edge can be attributed to lack of these skills. However, if these traditional Small Retail Outlets go under because of lack of competitiveness then the rate of unemployment would substantially increase and the risk of violence against other business brands in the townships would be real. It is, in light of this situation, that I undertook a qualitative study of traditional Small Retail Outlets. In the study, fifteen owners of traditional Small Retail Outlets were interviewed through semi-structured research questions.

\section{State of small retail outlets in South Africa}

Small Retail Outlets businesses in township areas show relatively high attrition rates. In a study conducted among the small business sample (business panel) in one township in 2007 and 2008, only just more than half the small businesses were still operating from the same premises. Business growth was particularly low among street vendors (hawkers) and homebased businesses (Ligthelm, 2009).

Ligthelm (2009) further suggests that the rapid increase in consumer expenditure by residents in township areas during the past decade, together with the fact that the overwhelming majority of township dwellers (83 \% in the case of Soweto, for example), expressed no intention of moving out of their townships, creates substantial market potential in these areas. This has resulted in a drastic change in township retail structures. Large shopping malls have been developed, or are under construction or in the planning phase in almost all township areas with sizeable population numbers. This development has resulted in heightened competition for small township businesses with a potential risk of considerable 
consumer expenditure displacement away from them to national chains and franchise businesses in the new shopping complexes.

These small retail outlets are facing a strong challenge to innovate and create an entrepreneurial competitive advantage in the face of the escalating number of shopping complexes. According to Industrial Development Corporation (2008), in South Africa, it is estimated that there are approximately 2 million small businesses, in the country, representing $98 \%$ of the total number of firms here. Small enterprises employ approximately $55 \%$ of the country's labour force and contribute approximately $42 \%$ to the country' wage bill. However, a problem for the country and its entrepreneurs is that $87 \%$ of these small businesses are survivalist. Fortunately the government has long recognized the vital contribution that entrepreneurs can play in economic development and the social up-liftment of its people. Consequently, a pivotal part of the government's ten year vision of the Accelerated and Shared Growth Initiative of South Africa (ASGISA) is for South Africa to become an entrepreneurial nation that rewards and recognizes those who see business opportunity and pursue it, a country with a vibrant and competitive small enterprise sector with enterprises that grow in both turnover and employment opportunities. Those who were once excluded from full participation in the economy including these small retail shop-owners in the townships will have access to support and development services, and be fully integrated into the different sectors of the South African economy, with access to local, national, African and other international markets (Liedholm, 2002:160).

Decline in the traditional steel making sector in many parts of the country calls for a serious enhancement of SMME's in these areas. In this regard, Lucas and Cooper (2004) point out that if the broader South African economy is to benefit from restructuring and the emergence of new business models like shopping complexes with renowned retail brands, it requires entrepreneurial individuals and teams of shop-owners to be able to recognise and effectively exploit the opportunities created.

Both established and newly created enterprises require individuals with knowledge, skills and attitudes that will enable them to develop innovative, leading edge products and services that underpin venture creation, growth and sustainable development in the face of increasing competition with these bourgeoning large retail outlets in townships.

\section{Challenges of small retail outlets}

The major challenge for these small retail outlets is to be competitive with these large retail outlets; otherwise they will face extinction. These small retail outlets cannot be static- they must continually adjust, adapt, or redefine themselves. This is a fundamental principle in a free market economy. However, in this entrepreneurial age, the rate of at which organizations including these retail outlets must transform themselves is accelerating and calls for them to be innovative, take risk and be proactive (Co \& Mitchell, 2006:348).

Many of those who have been part of the evolution (and revolution) of corporations in recent years have an amazing story to tell. The past quarter century has produced immense transformation in the functions, patterns, and cycles of organizations. Many of the conventional rules of business no longer apply. Fundamental assumptions about employees, products, control of resources, technologies, and markets have been challenged and in some cases discarded altogether. For many firms, turbulence in their external environments has become a way of life (Morris, Kuratko \& Covin, 2008:1). One editorial draws an analogy of fire regarding the impact of entrepreneurship innovation, stating that it is potentially destructive to existing norms and clears the way for innovation (Rogoff \& Heck, 2003:561).

Stated differently, a considerable amount of what occurs in these small retail enterprises may not be especially entrepreneurial, but rather, they appear to constitute basic survivalist activity, which creates little in the way of employment or wealth and is not a source of economic dynamism. Survivalist activities in business refer to businesses that are based on subsistence and have little prospects of growth. The challenge is to shift this personal 
survivalist mentality to return on investment by concentrating on basic entrepreneurial education and training in the small retail sector where historical, political, economic and social discrimination has created an undereducated black majority (Morris, Pitt \& Berthon,1996:73). These small retail outlets had to constitute entrepreneurial organisations that are innovative, pro-active, risk-taking or harness the ability to combine resources in a unique manner in order to create new products, services, processes, organisational forms, sources of supply and markets. They should be in the position to create value by bringing together unique combinations of resources to exploit an opportunity in order to grow (Lambing \& Kuehl, 200:14).

Liberating the entrepreneurial instincts of these small retail outlets' should be the focus of the leadership of the shop-owners' in order to ensure competitiveness, because by fostering entrepreneurship, they will be in the position to marshal and allocate their resources into a unique and viable posture based on its relative internal competencies and shortcomings. Embracing entrepreneurship is intended to make it the 'raison d'être' of their leadership and their ethos to face the rapid change of environment and also to be in the position to anticipate changes in the environment and contingent moves by intelligent opponents in the form of large retail outlets (Lebusa, 2007:5).

Another challenge that these small retail outlets face is for them to become entrepreneurial organizations. Kotelnikov (2003) posits that an entrepreneurial organization is one that promotes entrepreneurial activity by adapting structure, management and processes accordingly, in order to gain the required agility, speed, creativity and drive to act profitably upon specific opportunities.

According to Lumpkin and Dess (1996:141), an entrepreneurial organisation is in the position to employ its ability to use resources in a novel manner, leading to the creation of new products and services in its environment, so that it essentially represents organizational willingness and/or capabilities to act free of the existing constraints of the environment. In this regard, according to Lambing and Kuehl (2001:11), the one factor that distinguishes the entrepreneurial organisation from any other, is its ability to innovate, that is, the ability to innovate quickly and adapt to customers' changing demands, the aspects of which are viewed as comprising the major characteristics of entrepreneurial organisations. Therefore, it can be asserted that entrepreneurial organisations per definition focus on being pro-active and risk-taking with regards to the recognition of new opportunities, which enables them to develop new products and markets through a process of managed innovation.

\section{THEORETICAL FRAMING OF THE STUDY}

This study departs from the premise that small retail outlets are most likely to benefit from infusions of some specific type of entrepreneurship. While there are different understandings and perspectives on the meaning of entrepreneurship, there is a general consensus that an entrepreneur is one who exhibits some behaviours that are associated with taking initiative, being able to cope with affordable loss, pursuing calculated risks, effectively dealing with uncertainty and possible failure. In this sense, entrepreneurship can be understood as the process of developing some human conveniences by means of creating a new or improved benefit through practices of enterprising behaviour and receiving, in turn, some monetary and personal satisfaction (Wiklund and Shepherd 2005; McMullen and Shepherd 2006; Sarasvathy 2001; Coulter 2001; Lambing and Kuehl 2000; Lumpkin and Dess 1996; Sitkin 1992; Timmons and Spinelli 2004). Three basic aspects stand out from this definition in respect of an entrepreneur. First, the entrepreneur has to create something of value for both the entrepreneur and other human beings. Second, whatever is created needs to either be new or an improved version of an existing set of benefits. This is an aspect that creates a competitive edge for an entrepreneur. 
Aggressive competitiveness for an entrepreneur thus would mean constant creation of something new or improved which requires the devotion of considerable time, effort, resources and exhibition of enterprising behaviour. Third, these efforts of creating newness or improved something have to be driven by the strong motive of wanting to make a difference and deriving personal satisfaction from it with monetary considerations playing a secondary role. These three aspects derived from the definition formed the basis of analysing the views of the traditional Small Retail Outlets and guided the recommendation that I propose for developing Small Retail Outlets from subsistence towards sustainable businesses.

\section{RESEARCH METHODOLOGY}

The study employed qualitative methodology to data collection, analysis, organising and interpretation. Qualitative research, according to Gay and Airasian (2003:13), seeks to probe deeply into the research setting in order to obtain a deep understanding of the way things are and how participants perceive them. It also provides insights into what people believe and feel about the way they are, it allows the researcher to maintain a physical presence in the research setting, and it involves texts of written words and the analysis of collected data.

\section{Participants}

The population of this study consisted of owners of small retail outlets at townships in one district municipality (Sedibeng District Municipality) in South Africa. The said townships include Sharpeville, Boipatong, Bophelong, Sebokeng and Evaton.

These shop-owners were selected for the study because of the development of shopping complexes in the majority of the townships where these shop-owners believed that they control the market share. They found themselves in a changing and unstable environment in addition to the many challenges with which they were faced. Some of the challenges include, the relatively low growth rates of the small retail outlets sector in townships in general. The majority of entrepreneurs in these areas choose to operate in the informal sector precisely to avoid official business registration. Despite this, these small retail outlets fall under The South African National Small Business Act (Act No. 102 of 1996) and the National Small Business Amendment Bill (Bill No. 26926 of 2004: 2), which classify micro, very small, small and medium-sized businesses as those that employ less than 200 full-time equivalent paid employees. The focus of this study fell on very small businesses, as defined earlier.

\section{Data collection}

Information gathered from the literature review was used to develop and design an interview schedule to gather information from small retail owners at the townships.

The interviews were semi-structured, informal and conversational and were conducted during site visit observations so as to allow for as much flexibility as possible in order to gain in-depth data (Greef, 2002:302).

In all instances, field notes were taken and the impressions gained were jotted down after each interview (Greef, 2002:304). Coding and analysis were performed each day after the site visit to the shops. In this manner, data saturation and informational considerations became clear.

\section{Data analysis}

According to Merriam (1998:178), data analysis involves the process of making sense out of data collected by consolidating, reducing and interpreting what participants have said and what the researcher observed.

The interview focused on the entrepreneurship dimensions, that is, innovation, pro-activity and risk-taking. The shop owners were interrogated in terms of these dimensions in order to 
determine the extent to which they create new opportunities for innovative, pro-active and risk taking efforts in these retail outlets. These interviews also lay the ground for suggesting a slightly different approach to dealing with the challenges posed by the mushrooming shopping complexes.

\section{Population and sampling}

The study population stemmed from one district municipality (Sedibeng District Municipality) in South Africa and comprised only small retail outlets owners in the aforementioned townships. A purposive and convenient sample $(n=15)$ of owners of these small retail outlets from the townships of Sharpeville, Sebokeng, Bophelong, Evaton and Boipatong were selected.

According to Strydom and Venter (2002:334), in qualitative research, sampling occurs subsequent to clearly establishing the circumstances of the study and the directive, so that sampling is undertaken after the actual investigation has commenced. In this regard, sampling is relatively limited, is based on saturation, and is not representative, the size is not statistically determined and thus the sampling is non probable.

\section{FINDINGS}

\section{Innovation}

This refers to the process of implementing and using new ideas. It is, a willingness to emphasise novel ways of delivering products and services in a more effective, efficient and responsive manner, and appears to be minimal in these retail outlets (Maas \& Fox, 1997:64). In the context of the study and deriving from this definition, innovation involves identification of constraints and efforts of reducing and minimizing the constraints in order to create a new or improved benefit for human conveniences. In the interviews, the following views were elicited in relation to innovation:

Mr A, the owner of a retail outlet in Boipatong attributed his shop's underperformance to lack of innovation. He explained:

My challenge and that of many shops, I believe is that we are not employing novel ideas to run our businesses. We don't come up with new ways to better our services and delivering products to our customers. We are prone to imitating other people without actually being creative and innovative, that's why most of our offerings are the same.

\section{Risk-taking}

Taking a chance or embarking on a process even though there is no certainty of a positive or intended result, appear to constitute a major challenge for these retail outlets. There is a lack of willingness to commit significant resources to opportunities which stand a reasonable chance of costly failure and where the risks are typically calculated and yet manageable.

Shop owners seem to be attempting totake advantage of opportunities presented by developmentstaking place in theirtownships.

$\mathrm{Mr} \mathrm{B}$, a shop owner from Sebokeng stated:

Since there is a lot of development around here, how many of us ever thought of expanding their businesses to cater for the emerging market? I am aware of a few businesses that have taken the risk of expanding their shops, the rest of us are afraid to take those risks as we come with all sort of excuses not to do so. We are definitely not serving our community to their satisfaction hence they will go to malls and we had to blame ourselves for not acting promptly.

\section{Pro-activity}


A willingness to be the first to respond to needs for new or better products and services appears to be insufficient in these retail outlets. The owners appear to be lacking the ability to take the initiative whenever the situation demands. It is apparent that they do not seek opportunities, nor act quickly and decisively to make the most of the opportunity before somebody else does so.

Mrs C, a successful shop owner from Evaton observes:

We are very slow in coming up with and introducing new products and services to our people. We wait for someone to come up with something first and imitate her/him with a hope of making a killing. This is not how we are supposed to be doing things. I am of the view that, if I am serious of making money, I should always be the first to introduce something in the market so that by the time other people become aware, I have taken my share and becomes difficult for them to catch up with me.

In addition to the above mentioned entrepreneurial dimensions, the following dimensions emerged from the respondents:

\section{Competitive Aggressiveness}

There is an overwhelming indication that these retail outlets do not display an aggressive competitiveness when dealing with other competitors within their market. Strongly challenging the competition in order to achieve entry into the market or to strengthen their market position appears to be insufficient.

Mr D, from Boipatong had this to say:

Instead of us competing constructively to grow our businesses, we are locked on jealous behaviour and pulling down attitudes. We are inclined to always pointing out at others perceived weaknesses and planning how can we bring them down. We are quick in judging our competitors as crooks. We do not wishes (sic) others success, it is really endemic.

\section{Enterprising behaviour}

Findings in this regard demonstrated a lack of enterprising behaviour on the part of most shop owners. It became clear thatflexibility in responding to challenges, coping with and enjoying uncertainty, taking risky actions, solving risky actions, solving problems creatively, opportunity seeking, commitment to making things happen and persuading others appears to be not well conceived.

Shop Owner E, butchery owner from Bophelong commented:

We are not organised as businesses people here, we do not have a proper organised business structure or local association that we belong too here in the township. How do we then hope to grow and network if we cannot meet and discuss our challenges? Really, if we are serious about growing and becoming true entrepreneurs, a business organization is needed here and westop operating in silos as this is not helping us. We had to be bold enough to deal with our respective egos and unite so as to deal with the challenge posed by both shopping malls and influx of foreigners' businesses that are all over the our areas.

\section{Entrepreneurial strategy}

An overwhelming number of responses from the respondents indicated lack of entrepreneurial strategy in their businesses. Strategic entrepreneurship, which according to Ireland, Hitt and Sirmon (2003:963), involves simultaneous opportunity-seeking and advantage-seeking behaviours and which results in superior organizational performance, appears to be inadequate. These small retail ventures are ineffective in indentifying 
opportunities while also not being very successful in developing a competitive advantage which is needed to appropriate value from their current environmental challenges.

Mrs F, small retail outlet owner from Sebokeng explained:

Honestly, I am having a dream of expanding my business; I am envisaging that one day I own a big retail outlet here in the township and expanding to affluent areas in the suburb. As to how I will get there is a challenge, I am not having a clear operational plan or vision to achieve that. Since I am aware now that I am not having a clear vision, I think I would have to embark on developing one.

It also became apparent from the respondents that, when they were urged to address the bigger picture of their business future, beyond the immediate and the short-term, they responded in a dismissive manner such as: "Oh, the vision thing". This translated into the unspoken words- "We don't do the vision thing". They had never anticipated that so many malls would appear within their economic territory where this is currently working against them.

\section{Entrepreneurial training needs}

The author of this paper advances that the major objectives of enterprise education should be to develop enterprising people and inculcate an attitude of self-reliance by employing appropriate learning processes. The focus of teaching had to fall not on entrepreneurship (i.e., on the process of creating and developing individual businesses), but rather on developing people who express enterprising behaviour ( i.e., people who may want to run their own business, as well as those whose enterprising behaviour may take forms other than starting a business). The majority of the respondents alluded to the need for them capacitated with entrepreneurship skills and competencies as they believe that is the way to face the current situation of both big retail big brands and foreign shopowners in their own back-yards and became competitive.

Mr G, one the shop owner, testified:

I have been to a couple of courses or programmes of business management, where we were taught about business plans, financial accounting, marketing and any other subjects of running your business efficiently, I haven't been exposed to a course where I am taught to be competitive and become entrepreneurially savvy. I am not undermining the previous courses one has attended, they did brought about some visible changes on how I run my business, but I am saying, we need something that will equip us with knowledge that will makes us survive and triumph on this onslaught, otherwise we are finished. Just check how many shops has closed here in the township, really something needs to be done as of yesterday.

\section{Support from the local municipality enterprise development unit}

The National Framework for Local Economic Development makes it clear that local government does not create jobs. It goes on to point out that local economic development is about creating an environment in which to engage stakeholders to implementing strategies and programmes.

The majority of the owners of these small retail outlets is of the view that the local municipality development unit is not visible, is not supportive, and is nonexistent. They strongly believe that the unit is not doing what is supposed to be doing as they are alone in the maze of creating a vibrant economic milieu.

$\mathrm{Mr} \mathrm{H}$, a successful retail owner from Boipatong declared: 
I have never in my entire years of running this business being invited to a local economic development unit meeting here. The only time I got visitors from the municipality was when they came here to ascertain as to whether I am the rightful occupant of this premise. Since then I will be lying. I am not even aware of the role of that unit as communication with them is non-existence.

Mr I, a shop owner from Evaton lamented:

Maybe the reason these guys are not coming to us is the view that they think that we will need some financial assistance from them. Why are they so afraid of at least communicating with us? We are aware that there is such a unit, but we don't see it on the ground.

\section{DISCUSSION}

This study investigated the prospects of making small retail outlets aggressively competitive. On the basis of the literature review and the findings of this study it is not unreasonable to suggest that infusions of innovation into Small Retail Outlets would go a long way towards developing their competitiveness. This would most likely allow them to consider big brands and Small Retail Outlets of foreign nationals as healthy competition and move away from blame game and the false belief that local municipality has a responsibility to protect them. The unique design features of a Small Retail Outlet that could make these entities aggressively competitive would include, based on literature and gleaned the perspectives of the interviewed Small Retail Outlet owners, the following:

1. Develop a system of constantly scanning, analysing and understanding the business location and market opportunities that avail themselves at various stages of the market evolution and economic development even beyond the known business location to cater for business expansion and growth.

2. Develop mechanisms and strategies to leverage the emerging and new opportunities that avail themselves through ideas and prototypes that the owner developed or that the business location has made available as a result of new developments in order to either grow or diversify their existing business

3. Generate and deploy resources to iteratively test and develop new business opportunities within the framework of affordable losses.

4. Determine the team size, structure, internal systems, leadership style and key success variables to cater for the expanded business enterprise.

In this sense, small retail outlets outlets owners are most likely to develop the necessary skills to identify and exploit an opportunity, marshal resources such that investment in new or improved aspects of the business is conducted within the framework of affordable losses and finally, the owners would gain skills of assembling a winning team that function within well-established and constantly improved internal systems that innovative and entrepreneurial practices.

\section{Notes}

1. South African residential areas are divided into two i.e. suburb and townships which includes squatter camps. Suburb denotes an affluent settlement. Thus, white-only settlements were known as suburb while blacks-only settlements were known as townships.

2. A small retail outlet refers to enterprise operating from a township residential stand or home and engage in trading of consumer goods. 


\section{REFERENCES}

BUVIK, A. 2001. The industrial purchasing research framework: A comparison of theoretical perspective from micro economies, marketing and organizational science. Journal of Business and Industrial Marketing, 6: 439-450.

CHETTY, S. \& CAMPBELL-HUNT, C. 2003. Explosive international growth and problems of success amongst small to medium sized firms, International Small Business Journal, 21 (1):5-27.

CO, M.J. \& MITCHELL, B. 2006 Entrepreneurship education in South Africa: A nationwide survey, Journal of Education \& Training,48(5): 348-359.

COULTER, M. 2001. Entrepreneurship in action. Upper Saddle River, N.J: Prentice-Hall

CRESWELL, J.C. 2005.Educational Research: Planning, conducting \& evaluating quantitative \& qualitative research. Pearson Merrill Prentice Hall: New Jersey.

DAVIES, T.A. 2001.Entrepreneurship development in South Africa: redefining the role of tertiary institutions in a reconfigured higher education system. South African Journal of Higher Education, 15 (1): 32-39.

DETIENNE, D.R. \& CHANDLER, G.N. 2004.Opportunity identification and its role in the entrepreneurial classroom: a pedagogical approach and empirical test. Academy of Management Learning and Education, 3 (3): 242-257.

EYAL, O. \& INBAR, D.E. 2003.Developing a public school entrepreneurship inventory: Theoretical conceptualization and empirical examination.International Journal of Entrepreneurship Behaviour\& Research.9 (6):221-244.

GAY, L.R. \& AIRASIAN P. 2003. Educational research: Competencies for analysis and application. Upper Saddle River, N.J.: Merrill/Prentice-Hall.

GEM, (Global Entrepreneurship Monitor). 2005. Global Entrepreneurship Monitor: South African Report 2005. [Online] Available at: www.gsb.uct.ac.za/gsbwebb/userfiles/GEM2005.pdf. Accessed: 06 February 2011.

GREEF, M. 2002. Information collection: interviewing. (In De Vos, (ed). Research at grass roots for social sciences and human service professions. Pretoria: Van Schaik.

GRUNDLING, J.P. \& STEYNBERG, L. 2008. Academic entrepreneurship in South African Higher Education.Industry \&Higher Education. 22(1):9-17.

HISRICH, R.D. 2000.Entrepreneurial dimensions: The relationship of individual, venture, and environmental factors to success. Entrepreneurship Theory and Practice. 24(4):79-80.

INDUSTRIAL DEVELOPMENT CORPORATION. 2008. The importance of entrepreneurship for South Africa's economic development. [Web]www.info.gov.za/aboutsa/economy.htm. Access Date: 2008/12/01.

IRELAND, R.D, HITT, M.A and SIRMON, D.G. 2003. A model of strategic entrepreneurship: The construct and its dimensions. Journal of Management.29 (6): 963-989.

JOHNSON,JR. \& BOB, L. 1998. Resource dependency theory: A political economy model of organizations. International Encyclopedia of Public Policy and Administration.4:1969-1974.

KATZ, C.M., MACQUIRE,E.R. \& RONCECK, D.W. 2000. The creation of specialized police gang units: A macro-level analysis of contingency, social threat and resource dependency explanations. International Journal of Police Strategies and Management,25(3):472-506.

KOTELNIKOV, V. 2003. Entrepreneurial organization: promoting entrepreneurial activity inside established organizations. [Web] www.1000ventures.com. Access Date: 13/12/2008. 
KRUEGER, N.F. 2007. What lies beneath? The experiential essence of entrepreneurial thinking.Entrepreneurship Theory \& Practice.31 (1):123-138

LADZANI, W.M\& VAN VUUREN, J.J. 2002.Entrepreneurship training for emerging SMEs in South Africa. Journal of Small Business Management.40(2): 154-161

LAMBING, P. \& KUEHL, C.R. 2000.Entrepreneurship. New York: Prentice-Hall Inc.

LEBUSA, M.J. 2007. The prospects of fostering entrepreneurial praxes by school leadership at historically disadvantaged schools in Sedibeng Area.Vanderbijlpark: North-West University Publishing.

LIEDHOLM, C. 2002. Small Firm Dynamics: Evidence from Africa and Latin America. Small Business Economics, 18(1): 227-242.

LIGTHELM, A. 2009 .Small business success and failure in Soweto: A longitudinal analysis (2007-2008),Research Report no 377.

LUCAS, W.A. \& Cooper, S.Y. 2004. Enhancing self-efficacy to enable entrepreneurship: The case of CMI Connections.[Web]http:ssrn.com/abstract=568383. Access Date 2008/11/25.

LUMPKIN, G.T. \& Dess, G.G. 1996. Clarifying the entrepreneurial orientation construct and linking it to performance. Academy of Management Review, 21: 135-171.

MAAS, G.J.P. \& FOX, W. 1997.Entrepreneurship and public management. Cape Town: Juta Publishers.

MERRIAM, S.B. 1998. Qualitative research and case study applications in education. San Francisco: Jossey-Bass.

PROVINCE OF THE EASTERN CAPE ECONOMIC DEVELOPMENT \& ENVIRONMENTAL AFFAIRS. 2007. Local Economic Development Information Booklet. Indwe House: BishoSouth Africa.

MORRIS, M.H., PITT, L.F \& BERTHON, P. 1996. Entrepreneurial activity in the Third World informal sector: The view from Khayelitsha. International Journal of Entrepreneurial Behaviour \& Research, 8 (1) : 59- 76.

MORRIS, M.H, KURATKO, D.F. \& COVIN, J.G. 2008. Corporate Entrepreneurship and Innovation. $\left(2^{\text {nd }} \mathrm{ed}\right)$. Mason, Ohio: Thomson South-Western Publishing.

ORFORDO, J., HERRINGTON, M. \& WOOD, E. (eds). 2004. Global Entrepreneurship Monitor: South African Report. Cape Town: Centre for Innovation and Entrepreneurship, GraduateSchool of Business, University of Cape Town.

ROGOFF, E.G \& HECK, R.K.Z. 2003. Evolving research in entrepreneurship and family business: Recognizing family as the oxygen that feeds the fire of entrepreneurship. Journal of Business Venturing,18(5): 559-566.

SHANE, S. 2006. A general theory of entrepreneurship. The individual- opportunity nexus. Cheltenham: Edward Eldgar Publishing Limited.

STRYDOM, H. \& VENTER, L. 2002. Sampling and sampling methods (in De Vos, A.S. (ed).2002. Research at grass roots for social sciences and human service professions. Pretoria: Van Schaik.

SUCHAN, J \& DULEK, R. 1998. From text to context: An open systems approach to research in written business communication. Journal of Business Communication. 35(1): 87110.

SWANEPOEL, E, STRYDOM, J.W. \& NIEUWENHUIZEN, C.2010. An empirical

analysis of a private company's corporate social investment in SMME development in South Africa .Southern African Business Review, 14(1): 58-78. 
TIMMONS, A.T. \& SPINELLI, S. 2004. New venture creation, entrepreneurship for $21^{\text {st }}$ century. Boston: McGraw-Hill.

WIKLUND, J. and SHEPHERD, D. 2005. Entrepreneurial orientation and small business performance: A configurational approach, Journal of Business Venturing, 20: 71-91. 